\title{
Nitrogen regeneration and dissolved organic nitrogen release during spring in a NW Mediterranean coastal zone (Gulf of Lions): implications for the estimation of new production
}

\author{
Frédéric Diaz*, Patrick Raimbault \\ Laboratoire d'Océanographie et de Biogéochimie (UMR CNRS 6535), Centre d'Océanologie de Marseille, \\ Campus de Luminy, 13288 Marseille cedex 09, France
}

\begin{abstract}
Nitrogen regeneration fluxes of ammonium $\left(\mathrm{NH}_{4}{ }^{+}\right)$and nitrate $\left(\mathrm{NO}_{3}{ }^{-}\right)$as well as losses of dissolved organic nitrogen (DON) by phytoplankton were investigated over a 2 mo period (spring 1997) in a NW coastal Mediterranean area (Gulf of Lions) using ${ }^{15} \mathrm{~N}$-tracer techniques. Profiles of dissolved inorganic nitrogen (DIN) concentrations were almost uniform with values of 600,150 and $35 \mathrm{nM}$ for $\mathrm{NO}_{3}{ }^{-}, \mathrm{NO}_{2}{ }^{-}$and $\mathrm{NH}_{4}{ }^{+}$, respectively, except at the end of the study period when the upper layer became nitrogen-depleted ( $<50 \mathrm{nM}$ down to $40 \mathrm{~m}$ ). Chlorophyll (chl) distributions showed a surface maximum (to $0.85 \mathrm{mg} \mathrm{m}^{-3}$ ) and a deep maximum (to $1.25 \mathrm{mg} \mathrm{m}^{-3}$ ) at $40 \mathrm{~m}$. Plankton DIN utilization (net uptake) was most of the time highest at the surface, with rates reaching 62 and $40 \mathrm{nM} \mathrm{d}^{-1}$ for $\mathrm{NH}_{4}{ }^{+}$and $\mathrm{NO}_{3}{ }^{-}$, respectively. However, a deepening (to $60 \mathrm{~m}$ ) of maximum $\mathrm{NO}_{3}{ }^{-}$uptake rates with a corresponding deepening of the nitracline sometimes occurred during the experiment. Therefore, $f$-ratio profiles depicted maximum surface values $(\sim 0.40)$ at the beginning of the experiment and a deep maximum at the end. $\mathrm{NH}_{4}{ }^{+}$regeneration rates were 1 order of magnitude higher (up to $220 \mathrm{nM} \mathrm{d}^{-1}$ ) than nitrification and DIN loss (as DON) rates, and could largely sustain more than $100 \%$ of the plankton $\mathrm{NH}_{4}{ }^{+}$demand. Underestimation of $\mathrm{NH}_{4}{ }^{+}$uptake rates due to ${ }^{15} \mathrm{~N}$ isotope dilution had only a small effect on the $f$-ratio calculation (overestimation $<5 \%$ ). Nitrification occurred from the surface (10 to $\left.20 \mathrm{nM} \mathrm{d}^{-1}\right)$ down to the base of the euphatic layer $\left(30 \mathrm{nM} \mathrm{d}^{-1}\right)$, and corresponded to $90 \%$ and $\gg 100 \%$ of the plankton $\mathrm{NO}_{3}{ }^{-}$ demand at the surface and in the nitracline, respectively. Consequently, a great part of $\mathrm{NO}_{3}{ }^{-}$uptake did not correspond to new production and should be considered as regenerated production, particularly in the $\mathrm{NO}_{3}{ }^{-}$depleted surface layer. Profiles of DIN loss (as DON) well paralleled those of DIN net uptake with values highest at surface reaching 35 and $14 \mathrm{nM} \mathrm{d}^{-1}$ for $\mathrm{NH}_{4}{ }^{+}$and $\mathrm{NO}_{3}{ }^{-}$, respectively. DIN loss rates represented on average $\sim 23 \%$ of gross DIN uptake (gross DIN uptake = DIN losses + DIN net uptake) whatever the substrate was, indicating that (1) DIN loss (as DON) did not depend on the nitrogen source, and (2) DIN uptake was mostly due to phytoplankton and not to bacterioplankton, although the study area tended to be globally nitrogen-depleted and based on regeneration. Failure to account for DIN losses had no significant effect on the computation of $f$-ratios.
\end{abstract}

KEY WORDS: New production - Nitrogen regeneration $\cdot f$-ratios $\cdot$ DON release $\cdot{ }^{15} \mathrm{~N}$ tracer

\section{INTRODUCTION}

The role of coastal zones in the global biogeochemical carbon cycle, and their potential behavior to be a carbon source or sink, has been much debated by researchers for several years (Walsh et al. 1981, Rowe

•E-mail: diaz@com.univ-mrs.fr et al. 1986, Smith \& McKenzie 1991). Concepts of new and regenerated production, derived from ${ }^{15} \mathrm{~N}$-tracer experiments (Dugdale \& Goering 1967) and providing a model of the relation between primary productivity by phytoplankton communities and the 2 principal modes of nitrogen supply to the euphotic layer, enable us to know the potential role of coastal zones in the global carbon cycle. New nitrogen, mainly in the form of nitrate, is supplied by vertical transport driven by 
physical forcing mechanisms and supports new production. In contrast, regenerated nitrogen (ammonium, dissolved organics) is produced in situ in the upper layer by heterotrophic activities and fuels regenerated production. Eppley \& Peterson (1979) stated that global new production approximates the sinking flux of particulate organic matter to the deep ocean and they defined a $f$-ratio as being the part of new production in the total nitrogen production. Thus, new production and the $f$-ratio appear as indicators of the potential export production to the deep ocean, i.e. of the potential sequestration of atmospheric carbon by the biogenic flux (Platt et al. 1991). Furthermore, a specific feature of coastal environments is that nutrient recycling, and thus regenerated production, contributes to a significant fraction of the primary productivity in the euphotic layer (Eppley \& Peterson 1979, Eppley et al. 1979). In this regard, to accurately assess new and regenerated production, as well as the $f$-ratio, is of great interest in characterizing the importance of coastal environments in global biogeochemical cycles.

However, new findings on nitrogen regenerative fluxes and dissolved organic nitrogen (DON) release processes have shown that the new production concept has to be reevaluated (Bronk et al. 1994). For example, it has been recently recognized that failure to account for dissolved inorganic nitrogen (DIN) taken up by phytoplankton and released as DON results in an underestimate of DIN gross uptake rates (Bronk et al, 1994, Bronk \& Glibert 1991, Slawyk \& Raimbault 1995). The $f$-ratios obtained from conventional net nitrogen uptake rates are likely to be at odds with those made with gross uptake rates corrected for DON production. In addition, Glibert et al. (1982), Harrison (1983) and Harrison et al. (1987) have shown that in the case of ammonium isotope dilution (recycling of unlabeled substrate) can result in a significant underestimation of uptake rates and may consequently bias the assessment of $f$-ratios. Another important finding deals with the magnitude of the nitrification process in the euphotic layer. This microbial process (oxidation of ammonium to nitrate mediated by nitrifying bacteria) appears to be a key factor to consider in biogeochemical studies of marine primary productivity as well as nitrogen and carbon cycling (Ward 1986, Dore \& Karl 1996). If nitrification activity is important in the euphotic layer, this process is a source of in situ regenerated nitrate and can lead to an overestimation of new production and of the $f$ ratio when using net nitrate uptake rates obtained with the ${ }^{15} \mathrm{~N}$-tracer technique (Priscu \& Downes 1985 , Ward et al. 1989, Gentilhomme \& Raimbault 1994, Raimbault et al. 1999) since a fraction of the nitrate taken up is actually regenerated rather than new nitrogen (Eppley \& Renger 1986).
Estimations of nitrogen regeneration (both ammonium and nitrate) fluxes as well as of DIN loss (as DON) by phytoplankton are of great interest in the NW Mediterranean basin since (1) DON release has not yet been investigated; (2) only few studies have been done on ammonium regeneration (Selmer et al. 1993, Gentilhomme \& Raimbault 1994) and nitrification (Feliatra \& Bianchi 1993, Bianchi et al. 1994) in spite of their potential role in the nitrogen budget; (3) the $f$-ratio and new production so far have not been directly measured using the ${ }^{15} \mathrm{~N}$ tracer, but were only estimated from nutrient consumption and changes in $\mathrm{O}_{2}$ and $\mathrm{CO}_{2}$ fields (Coste et al. 1972, Minas \& Bonin 1988, Minas \& Codispoti 1993).

The main objectives of this study were to investigate the euphotic layer distribution and the magnitude of regenerative fluxes and losses of DIN (ammonium and nitrate) as DON ('DON release') in a coastal area of the NW Mediterranean Sea and to assess their potential role in the determination of new production.

\section{MATERIALS AND METHODS}

This work was carried out during the High Frequency Flux (HFF) experiment from March to May 1997 in the framework of the European Metro-Med and French PNOC (Programme National d'Océanographie Côtière) programs. Hydrological measurements and productivity experiments were conducted during 5 daily cruises $\left(\mathrm{HFF}_{2}\right.$ to $\mathrm{HFF}_{6}$, Table $1 ; \mathrm{HFF}_{1}$ was not sampled due to bad weather conditions) at 1 station close to a coastal area of the NW Mediterranean Sea (Fig. 1). In this area, hydrodynamics are dominated by the presence of the oligotrophic Modified Atlantic Water (MAW) (Lefèvre et al. 1997, Diaz et al. in press) from the North Mediterranean Current (Millot 1990) flowing along the continental slope. In the northern part, Coastal Water (CW) is influenced by the Rhone River inputs (Fig, 1).

Sampling. Water samples were collected at 8 standard depths $(5,10,20,40,60,80,100$ and $165 \mathrm{~m})$, using a CTDO rosette system with 81 Niskin bottles. Profiles of photosynthetically available radiation (PAR) were obtained with an irradiance profiling sensor (QSP200L, Biospherical Instruments ${ }^{\otimes}$ Inc.) fixed on the CTDO rosette system. Hydrological measurements were done with a conductivity-temperature-depthoxygen profiling system (CTDO Seabird, model 911+).

Nutrient analysis and chl biomass. Samples for ambient nitrite $\left(\mathrm{NO}_{2}{ }^{-}\right)$and nitrate $\left(\mathrm{NO}_{3}{ }^{-}\right)$concentrations were collected at each depth, in polyethylene flasks and immediately poisoned with $\mathrm{HgCl}_{2}$ $\left(20 \mu \mathrm{g} \mathrm{m} \mathrm{m}^{-1}\right.$. Kirkwood 1992) after sampling and stored at $5^{\circ} \mathrm{C}$ until analysis (1 d later). The samples were then 
Table 1. Euphotic zone (5 to $60 \mathrm{~m})$ depth-integrated rates of gross $\left(\rho_{g}\right)$ and net $(\rho)$ nitrogen uptake $\left(\mathrm{NO}_{3}{ }^{-}\right.$and $\left.\mathrm{NH}_{4}{ }^{+}\right)$and nitrification. Values were calculated by trapezoidal integration. nd: not determined

\begin{tabular}{|c|c|c|c|c|c|c|}
\hline \multirow[t]{2}{*}{ Cruise } & \multirow{2}{*}{$\begin{array}{c}\text { Date } \\
\text { (1997) }\end{array}$} & $\rho_{\mathrm{gNO}}$ & $\rho_{\mathrm{NO}_{3}}$ & $\rho_{g N H_{4}}$ & $\rho_{N_{4}}$ & Nitrification \\
\hline & & \multicolumn{5}{|c|}{$\left(\mathrm{mmol} \mathrm{m} \mathrm{m}^{-2} \mathrm{~d}^{-1}\right)$} \\
\hline $\mathrm{HFF}_{1}$ & Mar 16 & nd & nd & nd & nd & nd \\
\hline $\mathrm{HFF}_{2}$ & Mar 23 & 0.87 & 0.26 & 1.65 & 0.54 & 1.15 \\
\hline $\mathrm{HFF}_{3}$ & Apr 7 & 1.47 & 0.47 & 3.51 & 1.44 & 0.96 \\
\hline $\mathrm{HFF}_{4}$ & Apr 14 & 0.77 & 0.18 & 3.59 & 0.89 & 0.67 \\
\hline $\mathrm{HFF}_{5}$ & Apr 24 & 0.78 & 0.26 & 1.82 & 0.42 & 1.13 \\
\hline $\mathrm{HFF}_{6}$ & May 2 & 1.35 & 0.33 & 3.79 & 0.96 & 1.08 \\
\hline
\end{tabular}

processed at laboratory using a Technicon AutoAnalyser ${ }^{\otimes}$ II (precision: $\pm 25 \mathrm{nM}$ ) according to working procedures of Tréguer \& Le Corre (1975). Samples for ambient ammonium $\left(\mathrm{NH}_{4}{ }^{+}\right)$concentrations were collected in glass flasks. The reagents according to the Koroleff (1969) method were immediately added to the samples and concentrations were then measured manually at the laboratory $24 \mathrm{~h}$ later (precision: $\pm 30 \mathrm{nM}$ ). Samples for chl $(250 \mathrm{ml})$ were collected at each depth and immediately filtered on board onto baked $\left(450^{\circ} \mathrm{C}\right.$ for $24 \mathrm{~h}$ ) Whatman GF/F filters (25 $\mathrm{mm}$ in diameter) and stored in the dark at $-20^{\circ} \mathrm{C}$. Chl concentrations were determined by fluorimetry (fluorometer Turner Design ${ }^{*}$, model $10.005 \mathrm{R}$ ) by using the methanol extraction procedure (Raimbault et al. 1988).

Nitrogen flux experiments. The ${ }^{15} \mathrm{~N}$-tracer method was used to measure inorganic nitrogen uptake (Dugdale \& Goering 1967) and regenerative fluxes of $\mathrm{NH}_{4}{ }^{+}$(Glibert et al. 1982) and $\mathrm{NO}_{3}{ }^{-}$ (Slawyk \& Raimbault 1995). Samples were collected between 5 and $60 \mathrm{~m}$ depth, in acid-cleaned 1.21 polycarbonate (PC) bottles (Nalgene) and spiked with ${ }^{15} \mathrm{NH}_{4} \mathrm{Cl}$ or $\mathrm{Na}^{15} \mathrm{NO}_{3}$ (99.9 atom $\left.\%{ }^{15} \mathrm{~N}\right)$. Since initial $\mathrm{NO}_{3}{ }^{-}$ and $\mathrm{NH}_{4}{ }^{+}$concentrations were not immediately determined on board, $167 \mathrm{nM}$ of ${ }^{15} \mathrm{NH}_{4}{ }^{+}$and $86 \mathrm{nM}$ of ${ }^{15} \mathrm{NO}_{3}{ }^{-}$were added as a tracer leading to ${ }^{15} \mathrm{~N}$ enrichments ranging from 3.4 to $99.5 \%$ and from 28.1 to $99.6 \%$ of the corresponding ambient concentrations, respectively. The potential effect (enhancement) on uptake rates due to such tracer additions (Harrison et al. 1996) is discussed below. The 5, 20, 40 and $60 \mathrm{~m}$ samples were incubated under in situ simulated light conditions for $24 \mathrm{~h}$ at $50,25,8$ and $1 \%$ of surface light penetration, respectively, using a deck incubator cooled with sea surface water. At the end of the incubation, 100 and $20 \mathrm{ml}$ (for $\mathrm{NH}_{4}{ }^{+}$and $\mathrm{NO}_{3}{ }^{-}$, respectively) were withdrawn from the inoculation bottles in order to measure final $\mathrm{NH}_{4}{ }^{+}$and $\mathrm{NO}_{3}{ }^{-}$concentrations. Since filtration could not be immediately performed on board, samples were poisoned with $\mathrm{HgCl}_{2}$ (20 $\left.\mu \mathrm{g} \mathrm{ml}^{-1}\right)$ and kept in the dark at
Fig. 1. Station location during the High Frequency Flux (HFF) experiment in the Gulf of Lions and in the NW Mediterranean basin. Schematic view of the Gulf of Lions hydrodynamics (adapted from Millot 1990, Lefèvre et al. 1997): the Rhone River plume (RP), dilution area of the plume, Coastal Water (CW), and general circulation of Modified Atlantic Water (MAW) from the North Mediterranean Current (NMC) following the continental slope southwestward 
ambient temperature until laboratory treatment (12 to 24 h later).

To check for the potential effect of $\mathrm{HgCl}_{2}$ poisoning and sample storage on measurements of DIN uptake and losses as DON, the time course of particulate organic nitrogen (PON) concentration and ${ }^{15} \mathrm{~N}$ enrichment in 3 samples ( 2 from the investigated area, 1 from an eutrophic lagoon) was followed for $48 \mathrm{~h}$. All measurements were in triplicate. No significant $(p>0.05)$ alteration of the ${ }^{15} \mathrm{~N}$ content occurred throughout the storage period (compared to a 'time zero' sample filtered immediately after poisoning). However small losses of PON $(<7 \%)$ were observed during the first $24 \mathrm{~h}$.

At the laboratory, samples were gently vacuumfiltered ( $<100 \mathrm{~mm} \mathrm{Hg}$ ) through baked glass-fiber filters ( $\mathrm{GF} / \mathrm{F}$ ). The filters were dried at $60^{\circ} \mathrm{C}$ before mass spectrometric analysis. The $<\mathrm{GF} / \mathrm{F}$ filtrates were directly collected in a screw-capped $500 \mathrm{ml}$ Pyrex bottle (Duran Schott) and used to determine ${ }^{15} \mathrm{~N}$ enrichment of DIN and total DON (i.e. DON + PON $<$ GF/F) according to the methods described in Slawyk \& Raimbault (1995). In this procedure, all DIN forms $\left(\mathrm{NO}_{3}{ }^{-}\right.$ and $\mathrm{NH}_{4}^{+}$) as well as DON are removed from the filtrate by successive diffusion and reduction processes as ammonium sulfate anpropriate for the mass spectrometric assay. An unlabeled DIN carrier ( 3 and $5 \mu \mathrm{M}$ for $\mathrm{NH}_{4}{ }^{+}$and $\mathrm{NO}_{3}{ }^{-}$respectively) was added to the filtrates to provide sufficient nitrogen for the mass spectrometric analysis. For $\mathrm{NH}_{4}{ }^{+}$filtrates, an intermediate diffusion step was added in order to obtain the ${ }^{15} \mathrm{~N}$ abundance in the $\left(\mathrm{NO}_{3}{ }^{-}+\mathrm{NO}_{2}{ }^{-}\right)$pool, i.e. to estimate nitrification (here, oxidation steps from $\mathrm{NH}_{4}{ }^{+}$to $\mathrm{NO}_{2}$ and from $\mathrm{NO}_{2}^{-}$to $\mathrm{NO}_{3}^{-}$). Filters containing either PON or ammonium sulfate from filtrates were analyzed for ${ }^{15} \mathrm{~N}$ content using a continuous-flow method (Europa Scientific) in which Dumas combustion (Roboprep-CN) is linked on-line to a triple collector mass spectrometer (Tracer mass) via a capillary interface based on the design of Preston \& Owens (1983). Mass-spectrometric signals were used to determine ${ }^{15} \mathrm{~N}$ abundance and total nitrogen mass of samples.

Net DIN uptake rates were computed according to Dugdale \& Wilkerson (1986) from the equation:

$$
\rho_{\mathrm{DIN}}^{\mathrm{ner}}=\frac{R_{\mathrm{PON}}}{R_{\mathrm{TIN}} \times T} \times[\mathrm{PON}]
$$

where $R_{\text {PON }}$ and $R_{\text {OIN }}$ are the ${ }^{15} \mathrm{~N}$ atom $\%$ excess enrichment in the PON and DIN pool respectively, and [PON] the final PON concentration. $T$ corresponds to the incubation duration. The $\mathrm{NH}_{4}{ }^{+}$uptake rates were corrected for isotope dilution by using for $R_{\mathrm{DIN}}$ in Eq. (1) the mean value between initial and final enrichment in the ammonium pool $\left(\bar{R}_{\mathrm{NH}_{4}}\right)$. A few samples $(\mathrm{n}=8)$ were simultaneously filtered onto $0.2 \mu \mathrm{m}$ Anopore mem- branes. Net DIN uptake rates obtained from Anopore membranes were not significantly higher $(\mathrm{p}>0.10)$ than those obtained from GF/F filters, thus demonstrating that the utilization of GF/F filters did not result in an underestimation of net uptake in this coastal area. Similar results have been previously reported from the Equatorial Pacific (Raimbault et al. 1999).

During our study period, $\mathrm{NO}_{3}{ }^{-}$or $\mathrm{NH}_{4}{ }^{+}$concentrations often were of the order of 10 to $50 \mathrm{nM}$, and it was experimentally impossible to reduce the tracer addition to the ideal level (<10\% of ambient concentration, Dugdale \& Goering 1967). Furthermore, in 30 and $50 \%$ of samples (for $\mathrm{NO}_{3}{ }^{-}$and $\mathrm{NH}_{4}{ }^{+}$, respectively) concentrations were below the detection limit ( $<50 \mathrm{nM})$. Thus, our tracer additions to such low $\mathrm{NO}_{3}{ }^{-}$and $\mathrm{NH}_{4}{ }^{+}$samples may have involved a major perturbation of the $\mathrm{NO}_{3}{ }^{-}$and $\mathrm{NH}_{4}{ }^{+}$uptake (Allen et al. 1996, Harrison et al. 1996). As the main objective of this work was to demonstrate the sensitivity of $f$-ratios to nitrogen regeneration and to DIN loss, the primary estimators of the $f$-ratios (i.e. the net nitrogen uptake rates) had to be precisely measured. The use of nitrogen uptake kinetic parameters described by Harrison et al. (1996) allowed us to account for uptake rate enhancement according to the following equation given by Rees et al. (1999):

$$
\rho N_{\mathrm{H}}=\frac{\rho N_{\mathrm{O}}}{N_{\mathrm{sp}} /\left(K+N_{\mathrm{sp}}\right) \times\left(K+N_{\mathrm{A}}\right) / N_{\mathrm{A}}}
$$

where $\mathrm{N}$ is $\mathrm{NO}_{3}{ }^{-}$or $\mathrm{NH}_{4}{ }^{+}, \rho \mathrm{N}_{\mathrm{O}}$ is the original uptake $\left(n \mathrm{M} \mathrm{d}^{-1}\right), \rho N_{\mathrm{H}}$ is the uptake rate adjusted for enhancement by tracer $\left(\mathrm{nM} \mathrm{d}^{-1}\right), N_{\mathrm{sp}}$ is ambient + tracer DIN (nM), $N_{\mathrm{A}}$ is ambient DIN, and $K$ is the half-saturation constant ( $25 \mathrm{nM}$ ). For 3 samples $\left(\mathrm{HFF}_{5}\right), \mathrm{NH}_{4}{ }^{+}$concentrations were undetectable (i.e. $N_{\mathrm{A}}=0$ ). In this case, $N_{\mathrm{A}}$ was assumed to be $20 \mathrm{nM}$, the lowest concentration measured during the experiment. We assumed that DIN losses as DON were activated in the same way as net uptake rates and we applied to the DIN loss rates the same correction procedure as that performed for the net uptake rates. This assumption was made according to depth profiles of DIN loss which closely paralleled those of net DIN uptake (see 'Results').

Ammonium regeneration rates $\left(I_{\mathrm{NH}_{4}}\right.$ in $\mathrm{nM}-\mathrm{N} \mathrm{d} \mathrm{d}^{-1}$ ) were calculated using the initial and final ${ }^{15} \mathrm{NH}_{4}{ }^{+}$ enrichment in the filtrate according to the equation of Laws (1984). Nitrification rates ( $\rho_{N \mathrm{NT}}$, in $\mathrm{nM}-\mathrm{N} \mathrm{d}^{-1}$ ) were computed as follows (Raimbault et al. 1999)

$$
\rho_{\mathrm{NIT}}=\frac{R_{\mathrm{NO}_{3}}}{R_{\mathrm{NH}_{4}} \times T} \times\left[\mathrm{NO}_{3}\right]
$$

where $R_{\mathrm{NO}_{3}}$ is the ${ }^{15} \mathrm{~N}$ atom \% excess enrichment in the $\mathrm{NO}_{3}{ }^{-}\left(+\mathrm{NO}_{2}{ }^{-}\right.$) pool, $\mathrm{R}_{\mathrm{NH}}$ is the mean ${ }^{15} \mathrm{~N}$ atom $\%$ excess 
enrichment of the $\mathrm{NH}_{4}{ }^{+}$pool, and $\left[\mathrm{NO}_{3}\right]$ is the final $\mathrm{NO}_{3}{ }^{-}$concentration (initial + carrier addition).

The measurement of ${ }^{15} \mathrm{~N}$ abundance in the extracelIular DON pool $\left(R_{\mathrm{DON}}\right)$ allowed us to calculate the DIN $\left(\mathrm{NO}_{3}{ }^{-}\right.$or $\left.\mathrm{NH}_{4}{ }^{+}\right)$lost to the DON pool. The DIN loss rate $\left(p_{\text {DIN }}^{\text {loss }}\right)$ is given by the following equation (Slawyk et al. 1998):

$$
\rho_{\mathrm{DIN}}^{\text {ioss }}=\frac{R_{\mathrm{DON}}}{R_{\mathrm{DIN}} \times T} \times[\mathrm{DON}]
$$

where $R_{\mathrm{DON}}$ and $R_{\mathrm{DIN}}$ are the ${ }^{15} \mathrm{~N}$ atom $\%$ excess enrichment of the extracellular DON and DIN pool respectively, and where [DON] corresponds to the final extracellular DON concentration. $T$ is the incubation duration.

In addition to the classical $f$-ratio $(f)$, defined as the fraction of net $\mathrm{NO}_{3}{ }^{-}$uptake to total net DIN $\left(\mathrm{NO}_{3}{ }^{-}+\right.$ $\mathrm{NH}_{4}{ }^{+}$) uptake (Eppley \& Peterson 1979), a gross $f$-ratio $\left(f_{g}\right)$ was computed from corresponding gross uptake rates:

$$
f_{\mathrm{g}}=\frac{\rho_{\mathrm{NO}}^{\mathrm{gross}}}{\rho_{\mathrm{NO}}^{\mathrm{gross}}+\rho_{\mathrm{NH} 4}^{\text {gross }}}
$$

where $\rho_{\mathrm{DIN}}^{\text {gross }}$ (for nitrate and ammonium) was obtained from the expression in Slawyk et al. (1998):

$$
\rho_{\mathrm{DIN}}^{\text {gross }}=\rho_{\mathrm{DIN}}^{\text {loss }}+\rho_{\mathrm{DIN}}^{\text {net }}
$$

No corrections could be made for the possible overestimation of $f$-ratios by not including urea uptake (regenerated production) since this latter flux was not measured.

(a)

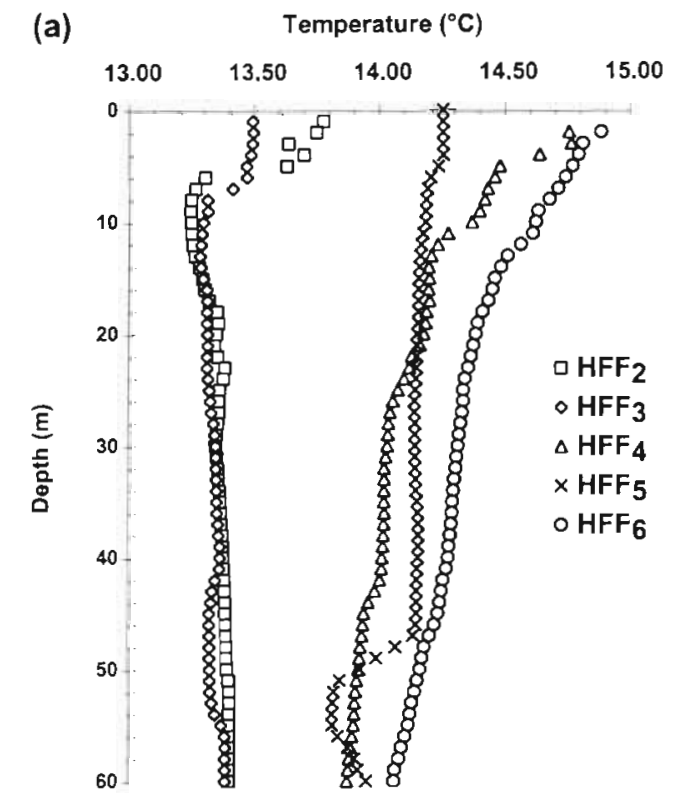

\section{RESULTS}

\section{Hydrological structures}

Vertical profiles of temperature (Fig. 2a) indicated a weak stratification of the upper layer throughout the experiment. On 4 of the 5 cruises, the mixed layer reached $\sim 6 \mathrm{~m}$ thickness. During the last cruise $\left(\mathrm{HFF}_{6}\right)$ this stratification disappeared since temperature decreased regularly from $14.92^{\circ} \mathrm{C}$ at the surface to $14.10^{\circ} \mathrm{C}$ at $60 \mathrm{~m}$. During the first 2 cruises depth versus salinity plots (Fig. $2 \mathrm{~b}$ ) revealed the presence of less salty coastal water $(\mathrm{CW})(<37.70$ between 8 and $15 \mathrm{~m})$ at the surface. Below this thin layer, salinity values were typical of the winter Modified Atlantic Water (MAW) (Millot 1990). During the last 3 cruises the warmer and more salty $\left(>13.90^{\circ} \mathrm{C},>37.90\right)$ MAW was predominant over the water column. PAR profiles indicated that the lower limit of the euphotic layer (taken as $1 \%$ of PAR) was at $60 \mathrm{~m}$ throughout the experiment.

\section{Inorganic nitrogen and $\mathrm{chl}$ distributions}

The DIN depth profiles generally revealed a severely nutrient-depleted upper layer except at the beginning of the experiment (Fig. 3). During the first 2 cruises, $\mathrm{NO}_{3}^{-}$concentrations ranged from 500 to $750 \mathrm{nM}$ and were relatively low for an early spring period (Coste et al. 1972). Depth profiles of chl (Fig. 4) showed typical patterns of late winter (surface maxi-

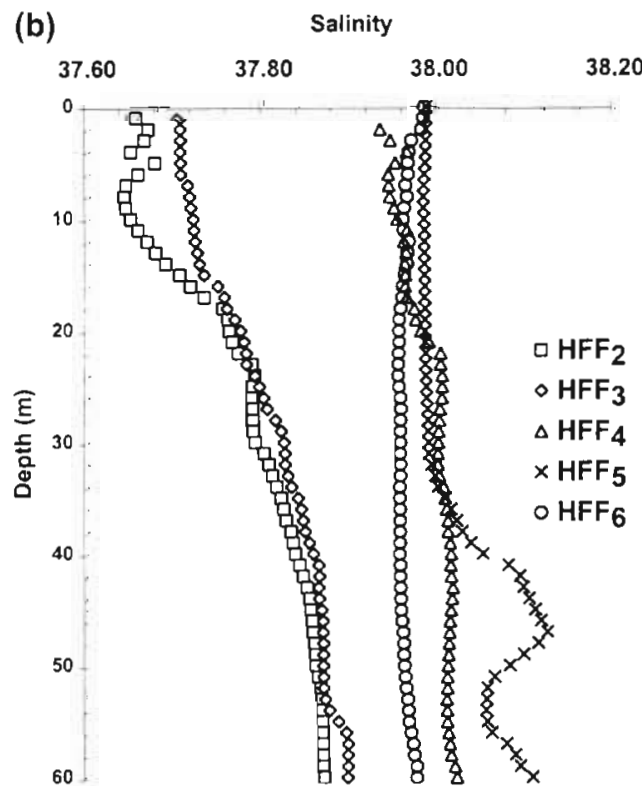

Fig. 2. Depth profiles of (a) temperature and (b) salinity in the euphotic layer during the 5 cruises (HFF to $_{2} \mathrm{HFF}_{6}$ ) of the $\mathrm{HFF}$ experiment. $\mathrm{HFF}_{1}$ was not sampled due to bad weather. Depth of euphotic layer $\sim 60 \mathrm{~m}$ 
mum, $\mathrm{HFF}_{2}$ ) and of early spring (high and uniform concentrations, $\mathrm{HFF}_{3}$ ). During the last 3 cruises, $\mathrm{NO}_{3}{ }^{-}$concentrations decreased abruptly (<50 $\mathrm{nM}$ ) in the upper layer down to $20 \mathrm{~m}\left(\mathrm{HFF}_{4,5}\right)$ and to $40 \mathrm{~m}\left(\mathrm{HFF}_{6}\right)$ with a marked nitracline. Parallel to the deepening of the nitracline, a marked deep chl maximum (DCM) was then observed at $40 \mathrm{~m}$. The $\mathrm{NO}_{3}{ }^{-}$exhausted layer was always deeper than the mixed layer and the water column was nutrient-stratified before being physically stratified. The $\mathrm{NO}_{2}^{-}$depth profiles showed high concentrations ( $>140 \mathrm{nM}$ ) down to $100 \mathrm{~m}$ at the beginning of the experiment $\left(\mathrm{HFF}_{2,3}\right)$ and then decreased to $<60 \mathrm{nM}$ during the following cruises. A slight $\mathrm{NO}_{2}{ }^{-}$ maximum could be observed and always began a few meters beneath the top of the nitracline. $\mathrm{NH}_{4}{ }^{+}$concentrations were generally low $(<70 \mathrm{nM})$ in the euphotic layer (except during $\mathrm{HFF}_{3}$ ) and the depth profiles presented only small variability except during $\mathrm{HFF}_{3}$ (peak of $260 \mathrm{nM}$ at $40 \mathrm{~m}$ ).

\section{Inorganic nitrogen utilization}

Net DIN uptake rates showed generally a surface maximum, and then decreased with depth (Fig. 5a,b). The maximum rates were always located at the same depth $\left(\mathrm{HFF}_{2,3}\right)$ or above the DCM $\left(\mathrm{HFF}_{4,5,6}\right) . \mathrm{NH}_{4}{ }^{+}$ uptake rates were generally highest at the surface and
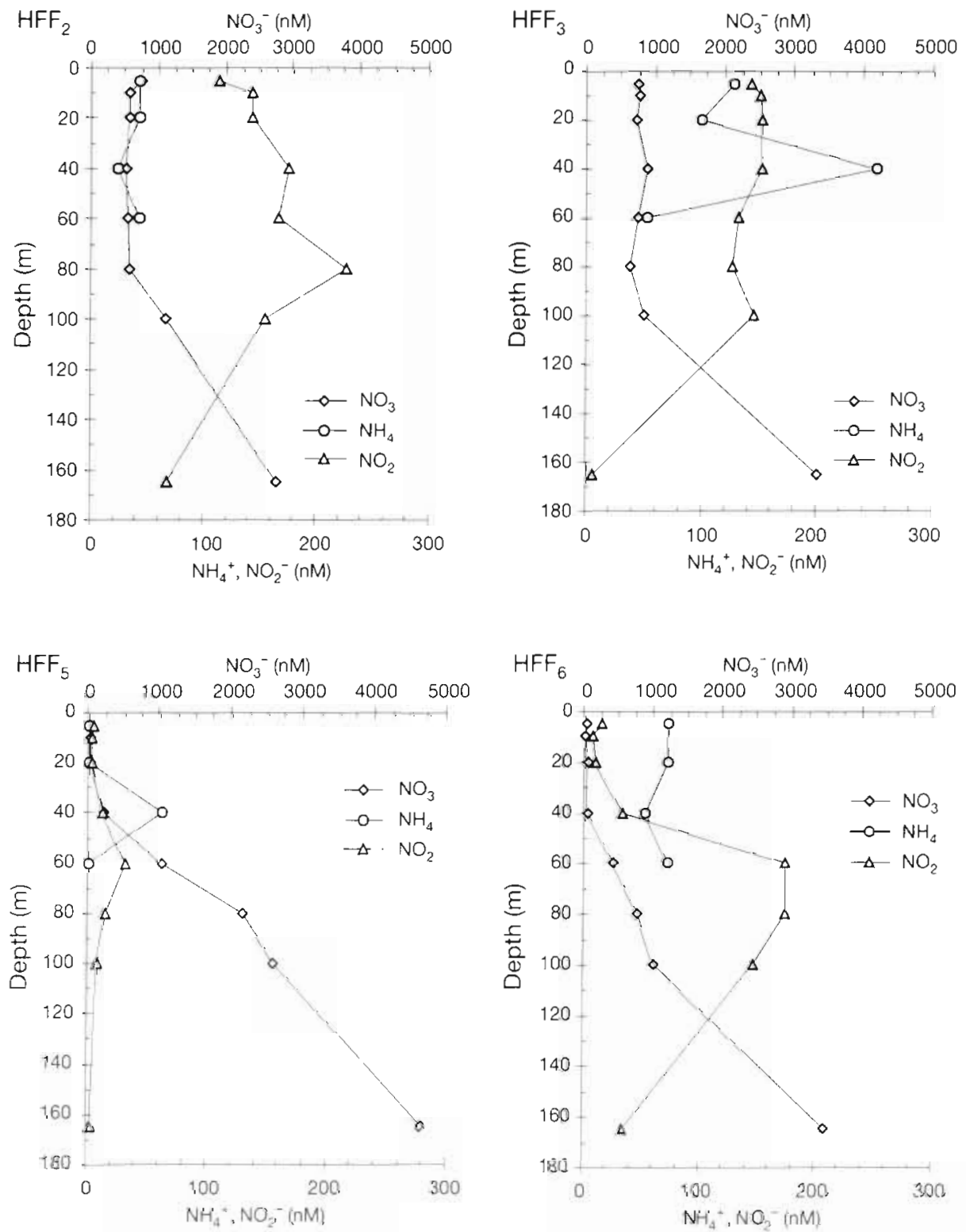

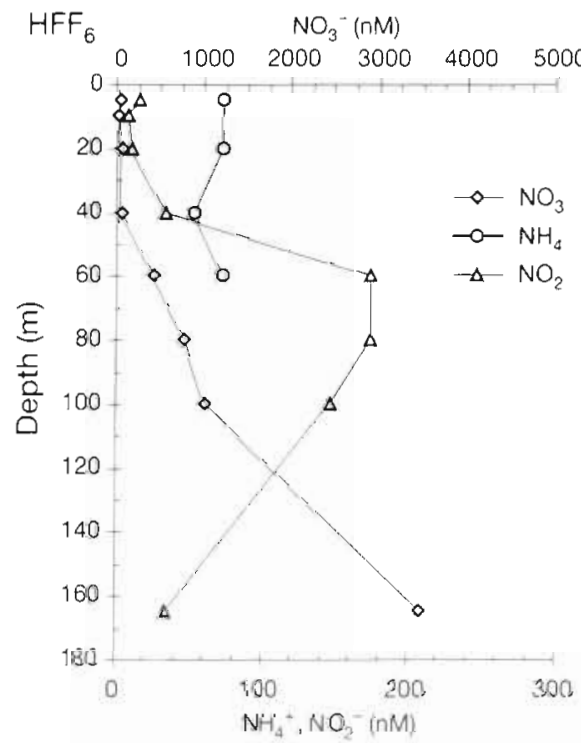

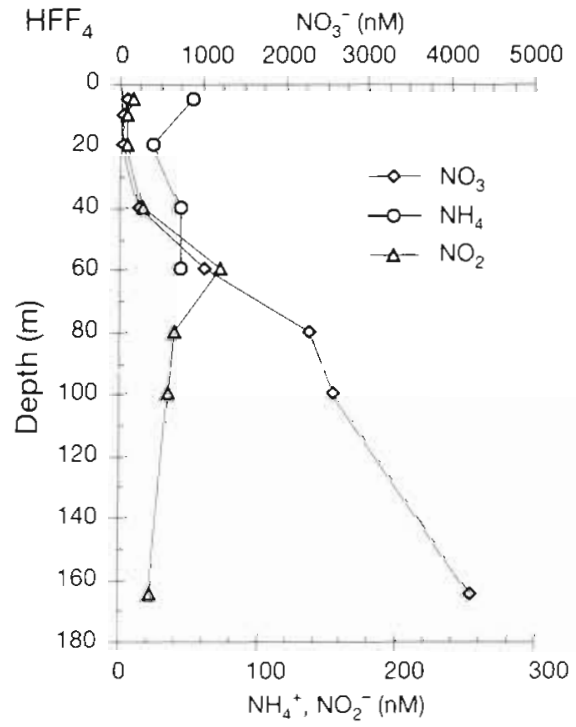

Fig. 3. Depth profiles of $\mathrm{NO}_{3}, \mathrm{NO}_{3}$ and $\mathrm{NH}_{4}$ - concentrations for each of the 5 cruises $\left(\mathrm{HFF}_{2}\right.$ to $\left.\mathrm{HFF}_{6}\right)$ 


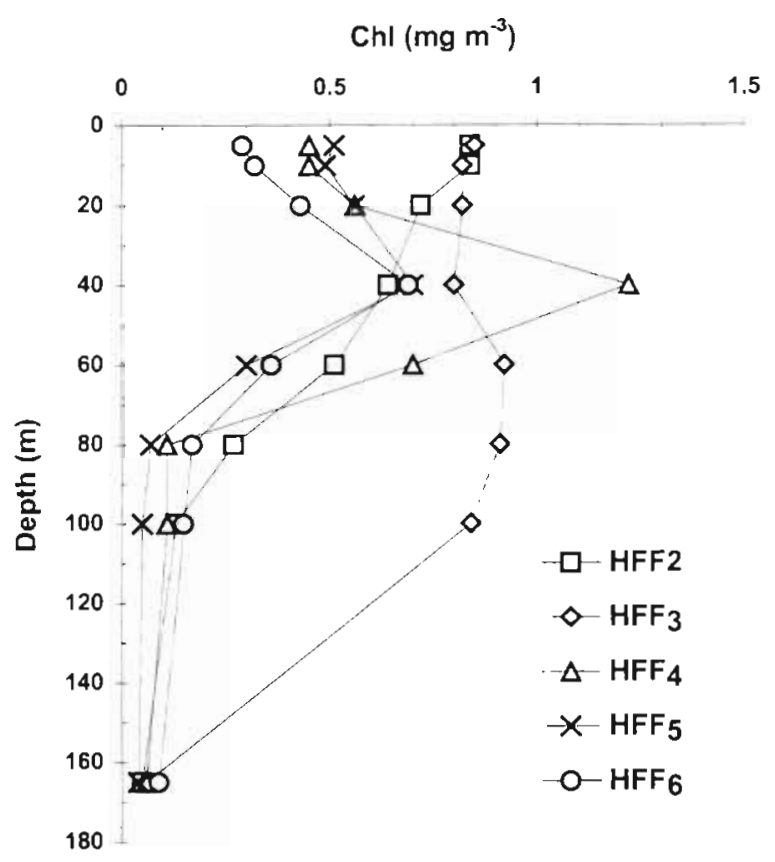

Fig. 4. Depth profiles of chlorophyll biomass (chl) for each of the 5 cruises $\left(\mathrm{HFF}_{2}\right.$ to $\mathrm{HFF}_{6}$ )

varied between 20 and $62 \mathrm{nM} \mathrm{d}^{-1}$ depending on the cruise. However, a subsurface maximum was seen at

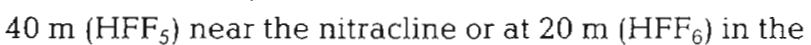
$\mathrm{NO}_{3}{ }^{-}$exhausted layer, and $\mathrm{NH}_{4}{ }^{+}$uptake rates often remained important until down to $40 \mathrm{~m} \mathrm{(>20} \mathrm{nM} \mathrm{d}{ }^{-1}$ ). In contrast, $\mathrm{NO}_{3}{ }^{-}$uptake rates seemed to be more light dependent and decreased rapidly with depth (rates < $20 \mathrm{nM} \mathrm{d}^{-1}$ from $40 \mathrm{~m}$ ). Maximum rates were found at the surface $\left(\sim 40 \mathrm{nM} \mathrm{d}^{-1}\right)$ during $\mathrm{HFF}_{2,3}$ and then paralleled the vertical distributions of $\mathrm{NO}_{3}{ }^{-}$concentrations during the last cruises, during which a deepening of the maximum $\mathrm{NO}_{3}{ }^{-}$uptake rate was observed following the nitracline deepening. According to these latter distribution patterns, depth profiles of the $f$-ratio (Fig. 6a) showed highest values $(0.40)$ at the surface at the beginning of the experiment $\left(\mathrm{HFF}_{2,3}\right)$, and then the maximum (up to 0.70 ) successively deepened down to

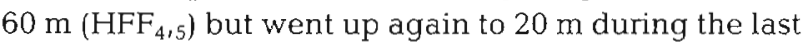
cruise $\left(\mathrm{HFF}_{6}\right)$

\section{Regenerative nitrogen fluxes}

Ammonium regeneration $\left(I_{\mathrm{NH}_{4}}\right)$ depth profiles (Fig. 5c) generally showed a maximum rate at the surface ( 50 to $220 \mathrm{nM} \mathrm{d}^{-1}$ ) and were higher (up to double) in the $\mathrm{CW}\left(\mathrm{HFF}_{2,3}\right)$ than in the $\mathrm{MAW}\left(\mathrm{HFF}_{4,5,6}\right)$. Then rates decreased with depth $\left(<50 \mathrm{nM} \mathrm{d}^{-1}\right.$ at $\left.60 \mathrm{~m}\right)$. However, a subsurface maximum (up to $170 \mathrm{nM} \mathrm{d}^{-1}$ ) was found $\left(\mathrm{HFF}_{4}\right)$ at $20 \mathrm{~m}$, corresponding to the lower limit of the $\mathrm{NO}_{3}{ }^{-}$exhausted layer. Maximum regeneration was located within (or above) the DCM (Fig. 4) as for stratified water column (Harrison et al. 1983). Uptake rates $(U)$ were compared with the regeneration rates $(R)$ in terms of an $U: R$ ratio for $\mathrm{NH}_{4}{ }^{+}$. Depth profiles of this ratio (Fig. 6b) did not show a marked pattern throughout the experiment. $U: R$ ratios were mostly $<1$. except in 1 case at the surface, indicating that regeneration could most of the time sustain much more than $100 \%$ (mean: $315 \%$, range: 79 to $793 \%$ ) of the $\mathrm{NH}_{4}^{+}$ demand, thus explaining the significant $\mathrm{NH}_{4}{ }^{+}$accumulation observed in the euphotic layer.

The vertical distribution of nitrification (Fig. 5d) showed only small variability between the different cruises, and rates were globally 1 order of magnitude less than those of $\mathrm{NH}_{4}^{+}$regeneration (Fig 5c). Depth profiles revealed that nitrification occurred within the whole euphotic layer: nitrification rates were stable 110 to $20 \mathrm{nM} \mathrm{d}^{-1}$ ) from the surface down to $40 \mathrm{~m}$ and significantly increased at the base of the euphotic layer (17 to $30 \mathrm{nM} \mathrm{d}^{-1}$ ). This pattern was slightly modified at the surface during $\mathrm{HFF}_{3}$, with increasing rates in the $\mathrm{CW}$ layer. $\mathrm{NO}_{3}^{-}$uptake compared to nitrification in terms of the $U: R$ ratio generally dominated in the upper layer; nitrification potentially sustained $88 \%$ (range: 56 to $120 \%$ ) of the phytoplankton $\mathrm{NO}_{3}{ }^{-}$demand. However, in the deep layer nitrification rates were 2 to 11 times greater than corresponding $\mathrm{NO}_{3}{ }^{-}$ uptake rates (Fig. 6b).

\section{DON release: DIN loss as DON}

DIN loss rates as DON (Fig. 5e,f) decreased in most cases with depth and were very low at the bottom of the euphotic layer (for $\mathrm{NO}_{3}^{-}$losses, particularly). Depth profiles closely paralleled the DIN uptake profiles, indicating that the DON release process was likely linked to autotrophic communities. Loss rates of $\mathrm{NO}_{3}{ }^{-}$appeared to be much lower (max. $13 \mathrm{nM} \mathrm{d}^{-1}$ ) and less variable than those of $\mathrm{NH}_{4}^{+}$(max. $35 \mathrm{nM}$ $\mathrm{d}^{-1}$ ). Maximum loss rates of ${ }^{15} \mathrm{NH}_{4}{ }^{+}$occurred at the end of the survey in the $\mathrm{NO}_{3}{ }^{-}$exhausted layer, whereas those of $\mathrm{NO}_{3}{ }^{-}$were highest at the beginning in the upper $\mathrm{NO}_{3}{ }^{-}$rich waters. Comparisons between net and gross uptake rates $\left(\rho: \rho_{g}\right)$ revealed a mean ratio ranging between 0.70 and 0.80 depending on the sampled depth (Fig. $7 \mathrm{a}$ ). The ratio was relatively uniform over the water column. However, the mean losses of $\mathrm{NO}_{3}{ }^{-}$tended to decrease at the surface and at the bottom of the euphotic layer, contrary to those of $\mathrm{NH}_{4}{ }^{+}$. The standard deviation (SD) of $p: p_{g}$ increased with depth $( \pm 7 \%$ at $5 \mathrm{~m}$ and $\pm 20 \%$ at $60 \mathrm{~m})$, which may be partly explained by the very low uptake and loss rates (close to the limit of detection) at 
(a)

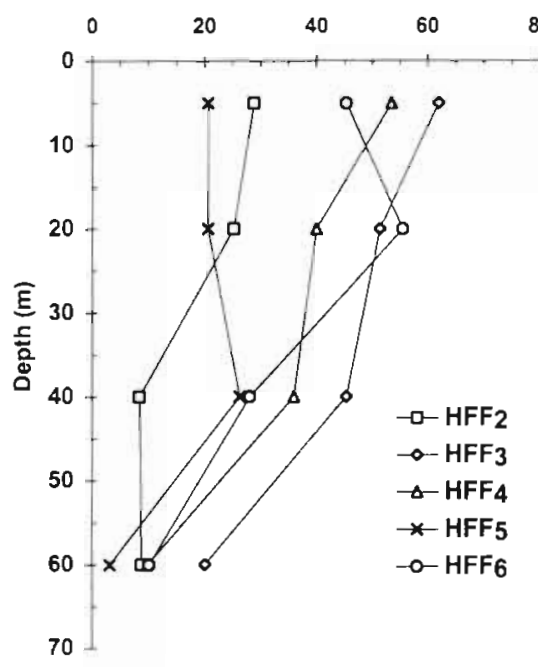

(c)

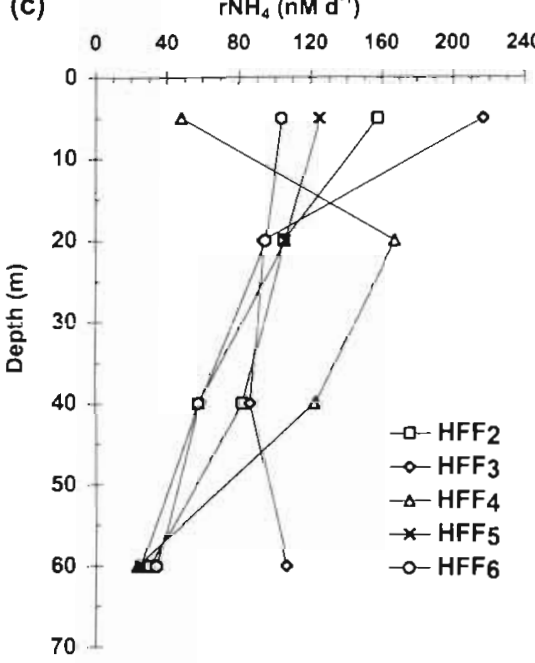

(e) $\quad{ }^{15} \mathrm{NH}_{4}{ }^{+}$losses $\left(\mathrm{nM} \mathrm{d} \mathrm{d}^{-1}\right)$

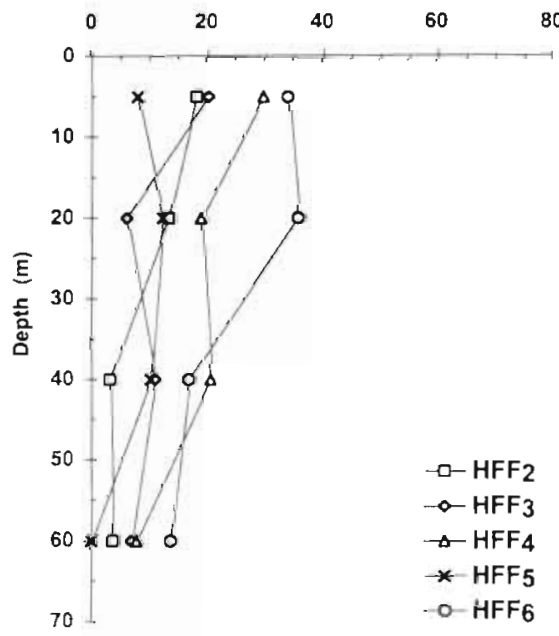

(b) $\quad \mathrm{NO}_{3}$ uptake (nM d $\left.\mathrm{d}^{-1}\right)$

80

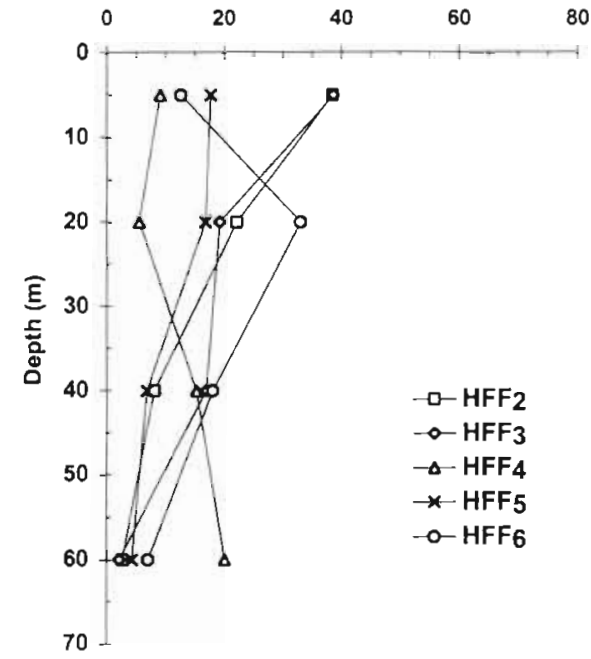

(d) nitrification rate $\left(\mathrm{nM} \mathrm{d}^{-1}\right)$

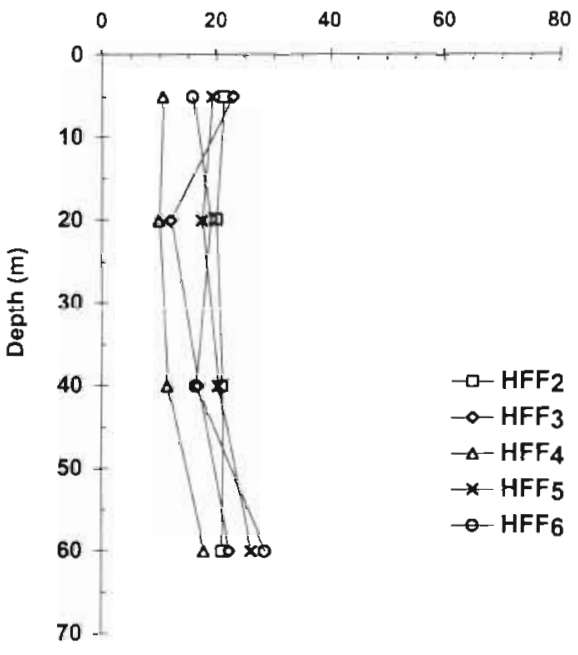

(f) $\quad{ }^{15} \mathrm{NO}_{3}^{-}$losses $\left(\mathrm{nM} \mathrm{d}^{-1}\right)$

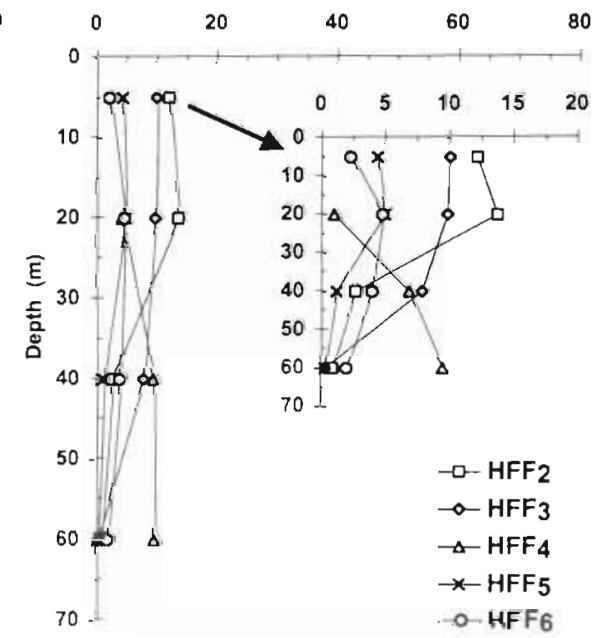

Fig. 5. Vertical profiles of (a) $\mathrm{NH}_{4}{ }^{+}$and (b) $\mathrm{NO}_{3}$ net uptake, (c) $\mathrm{NH}_{4}{ }^{+}$and (d) $\mathrm{NO}_{3}{ }^{-}$regeneration, and (e) $\mathrm{NH}_{4}{ }^{*}$ and (f) ${ }^{15} \mathrm{NO}_{3}{ }^{-}$losses to DON pool. Note the change in scale of the $x$-axis in (c) 

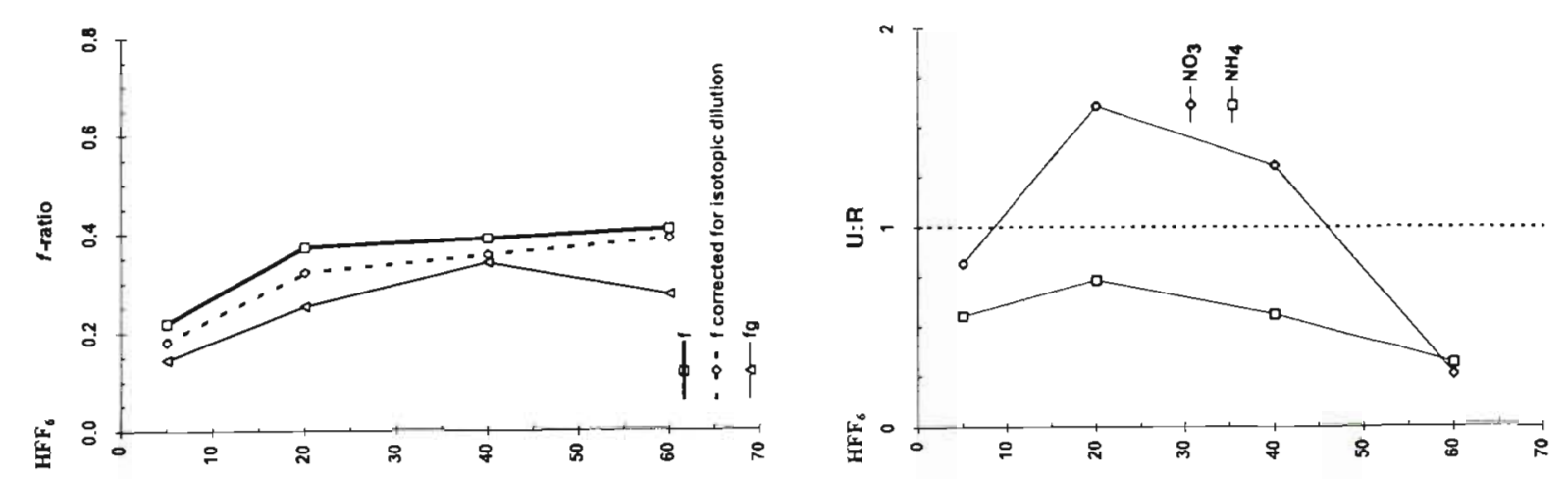

0
0
0
0
0
0
0
0
0
0
0
0
0
0
0
0
0
0
0
0
0
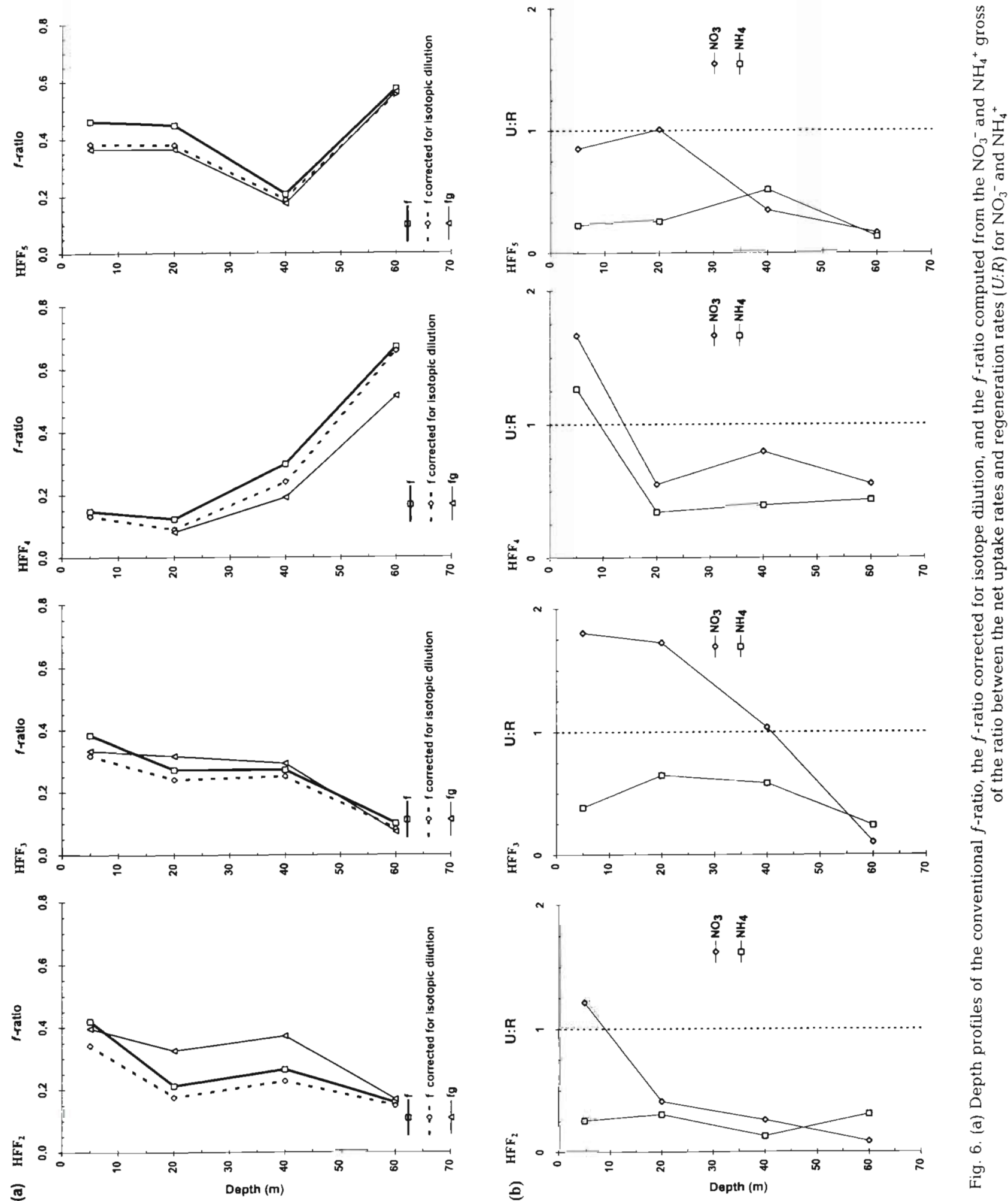
(a)

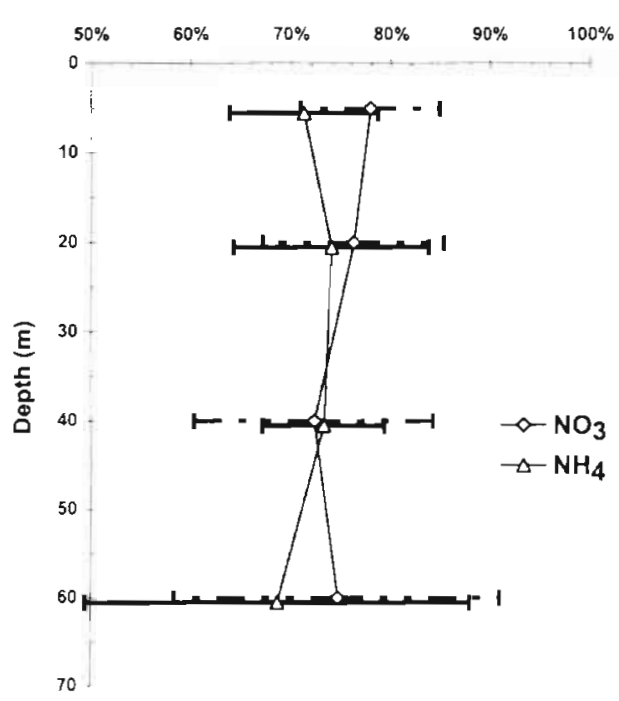

(c)

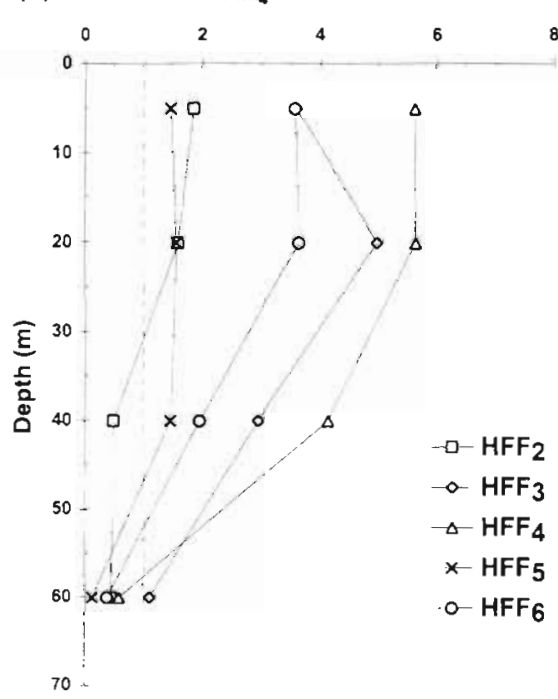

(b)

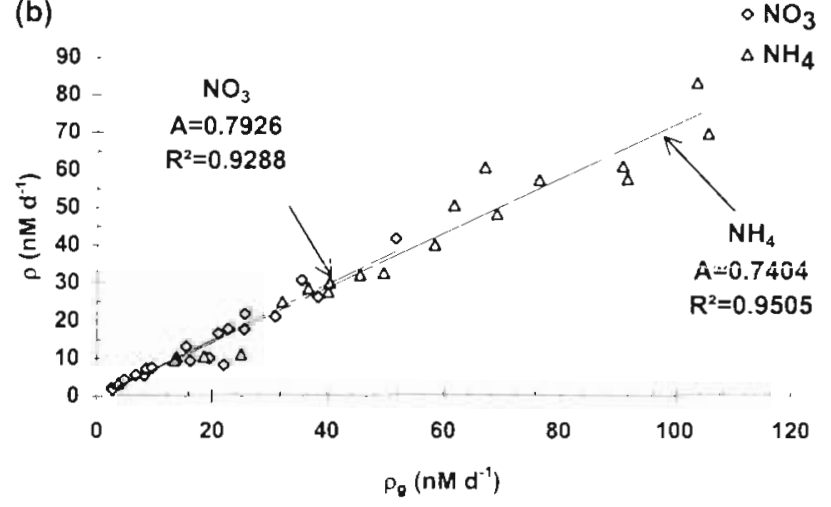

Fig. 7 (a) Depth profiles of the net uptake:gross uptake ratio $\left(p: p_{g}\right)$. Values are means of 5 samples. Horizontal bars represent \pm SD. (b) Net uptake rates $(\rho)$ versus gross uptake rates $\left(\rho_{g}\right)$ where $A$ represents the slope obtained from a model II regression analysis, and $\mathrm{R}^{2}$ is the percentage of variation of $\rho$ explained by the model II regression. (c) Depth profiles of the net $\mathrm{NH}_{4}{ }^{*}$ uptake:nitrification ratio

depth. A plot of net uptake rate $(\rho)$ versus gross uptake rate $\left(\rho_{g}\right)$ (Fig. 7b) gave a slope of $0.7404(95 \%$ confidence interval, CI: $[0.7399$ to 0.7408$]\}$ and of 0.7926 (95\% CI: $[0.7916$ to 0.7936$]$ ) for $\mathrm{NH}_{4}{ }^{+}$and $\mathrm{NO}_{3}{ }^{-}$uptake experiments, respectively with an intercept close to zero (model II, Sokal \& Rohlf 1995). Both slopes were statistically different from $1.0(p<0.01)$ but were not significantly $(p>0.50)$ different from each other Thus, DIN losses were significant and represented $\sim 23 \%$ of gross uptake during the $24 \mathrm{~h}$ incubation experiments.

\section{DISCUSSION}

According to Dugdale \& Wilkerson (1988), it may be incorrect to use the concept of new and regenerated production (sensu Dugdale \& Goering 1967) in the Mediterranean Sea since allochthonous nutrients from rivers, land run-off and sewage plants deliver new nitrogen in the form of nitrate and ammonium to the marine system. In particular, inputs of ammonium by terrestrial and Rhone River discharges must be considered as new nitrogen so that $\mathrm{NH}_{4}{ }^{+}$uptake measured may no longer be considered as regenerated production. However, in spite of these nutrient inputs, the concept of new and regenerated production may still apply to this marine coastal area for at least 2 reasons: (1) hydrodynamics in the area are dominated by the near-shore presence of oligotrophic MAW (i.e. open ocean conditions) and (2) the influence of the Rhone River plume is only weak (Fig. 1) especially for $\mathrm{NH}_{4}{ }^{+}$ (only $5 \%$ of the total nitrogen discharge; Moutin et al. 1998). 


\section{Nitrogen regeneration and new production}

Our study showed that the regenerative nitrogen fluxes are important during spring in the NW Mediterranean Sea. As previously observed in other coastal areas (Glibert 1982), DIN regeneration was more than sufficient to sustain the plankton DIN demand (especially for $\mathrm{NH}_{4}^{+}$) in this coastal area, and probably controlled phytoplankton growth during spring. Nitrification depth profiles showed the same pattern as those found in other areas (Olson 1981a, Ward et al. 1984, Eppley \& Renger 1986, Ward 1987, Ward \& Zafiriou 1988), confirming that this process is partly controlled by light (Horrigan et al, 1981, Olson 1981b, Ward 1985), i.e. the lower the light intensity, the higher the nitrification. Nevertheless, in contrast to findings of Dore \& Karl (1996), nitrification was detected up to the surface during spring and appeared not to be fully inhibited by light. As observed in other studies (Ward et al. 1989, Dore \& Karl 1996, Raimbault et al. 1999) of oceanic (north and central Pacific) and coastal (Bight of California) waters respectively, in situ nitrification can obviously fuel the daily $\mathrm{NO}_{3}{ }^{-}$net demand of phytoplankton. Nitrification and $\mathrm{NH}_{4}{ }^{+}$uptake both occurred throughout the euphotic layer, and microorganisms responsible for these 2 processes (bacteria and phytoplankton) likely compete with each other for $\mathrm{NH}_{4}^{+}$(Ward et al. 1989, Bianchi et al. 1994). The $\rho_{\mathrm{NH}_{4}}$ :nitrification ratio was $<1$ near the bottom of the euphotic layer (Fig. $7 \mathrm{c}$ ), indicating that $\mathrm{NH}_{4}{ }^{+}$is preferentially used as a source of energy for nitrifiers rather than a structural N-source for all phytoplankton communities. Only sparse data on in situ nitrogen regeneration exist from the Mediterranean Sea: Selmer et al. (1993) found regeneration rates close to ours during spring in the Bay of Villefranche-sur-Mer, ranging between 4 and $12 \mathrm{nM} \mathrm{h}^{-1}$. Gentilhomme \& Raimbault (1994) observed higher rates in the Algerian Current frontal area (SW Mediterranean Sea), ranging from $25 \mathrm{nM} \mathrm{h}^{-1}$ at the surface to $125 \mathrm{nM} \mathrm{h}^{-1}$ in the DCM. Some measurements performed during spring in other coastal marine systems (Harrison 1978, Cochlan 1986, 'Hanson \& Robertson 1988) gave higher rates (from 2 to $240 \mathrm{nM} \mathrm{h}^{-1}$ ), but comparisons between their hourly and our daily rates are difficult since regeneration has been shown to vary greatly with the time of the day (Glibert 1982). Furthermore, in the latter studies (particularly in those of Harrison and of Cochlan) rates correspond to potential rates due to the large excess $\mathrm{NH}_{4}{ }^{+}$enrichment compared to the initial in situ $\mathrm{NH}_{4}{ }^{+}$concentrations (Selmer 1988). This latter author observed an increase in $\mathrm{NH}_{4}{ }^{+}$regeneration rates with tracer enrichment up to $100 \%$. Given the relative high ${ }^{15} \mathrm{NH}_{4}{ }^{+}$enrichments compared to the ambient $\mathrm{NH}_{4}{ }^{+}$concentrations in our experiments, we can assume that our regeneration rates are close to potential rates.
As far as nitrification in concerned, our rates are close to those reported for oligotrophic areas by Ward (1987) and Eppley et al. (1990). Gentilhomme \& Raimbault (1994) measured higher rates (up to $10 \mathrm{nM} \mathrm{h}^{-1}$ for $\mathrm{NH}_{4}{ }^{+}$oxidation) in the euphotic layer of a frontal area (Algerian current, SW Mediterranean Sea) while Feliatra \& Bianchi (1993) found very high rates (up to $370 \mathrm{nM} \mathrm{d} \mathrm{d}^{-1}$ for $\mathrm{NH}_{4}^{+}$oxidation) in the plume of the Rhone River. However, these latter authors applied a different method based on the measurement of inorganic carbon uptake by nitrifiers and of changes in $\mathrm{NO}_{2}{ }^{-}$Concentration (Feliatra \& Bianchi 1993, Bianchi et al. 1994). It is important to keep in mind that our $\mathrm{NO}_{3}{ }^{-}$ regeneration rates may have been overestimated, since we measured the production of both $\mathrm{NO}_{2}^{-}$and $\mathrm{NO}_{3}{ }^{-}$from $\mathrm{NH}_{4}{ }^{+}$and not only of $\mathrm{NO}_{3}{ }^{-}$Another potential artifact is the enhancement of nitrification by high tracer additions. However, the low variability of nitrification rates ( $\mathrm{Fig} .5 \mathrm{~d}$ ) seems to indicate that this process was weakly activated by high tracer additions. During spring, the Gulf of Lions appeared to be an area with relatively low nitrogen regeneration, although in situ regeneration was high enough to sustain the nitrogen demand (especially for $\mathrm{NH}_{4}{ }^{+}$) of the phytoplankton and bacterioplankton communities.

Given the relative importance of regenerative processes in the euphotic layer of our study site, we tried to assess the implication of these processes on the computation of the $f$-ratio and on the concept of new production. First, $\mathrm{NH}_{4}^{+}$uptake must be corrected for isotopic dilution during $\mathrm{NH}_{4}{ }^{+}$regeneration (underestimation). Fig. 6a shows that $f$-ratios, including $\mathrm{NH}_{4}^{+}$ uptake rates corrected for isotopic dilution, were systematically lower than conventional $f$-ratios. Plotting the conventional $f$-ratio versus the $f$-ratio corrected for isotopic dilution gave a slope (model II) of 0.970 (95\% CI: $[0.904$ to 1.041$])$, which was not significantly different from 1 . The possible over-estimation of the $f$-ratio due to the non-inclusion of uptake (and regeneration) of urea could not be evaluated, since fluxes of this organic nitrogen compound have not been investigated in this area. However, it should be noted that noninclusion of $\mathrm{NH}_{4}{ }^{+}$isotope dilution involves much lower overestimation in $f$-ratios $(-3 \%)$ than those due to the non-inclusion of urea uptake rates $(17 \%$, Wafar et al. 1995). Also, this study demonstrated a significant $\mathrm{NO}_{3}{ }^{-}$ production by nitrification, relative to $\mathrm{NO}_{3}{ }^{-}$uptake, which implies that an important part of $\mathrm{NO}_{3}{ }^{-}$taken up by phytoplankton actually may be regenerated rather than new nitrogen. However, it is difficult to assess the contribution of in situ nitrification to the total $\mathrm{NO}_{3}$ taken up, since the measurement of $\mathrm{NO}_{3}{ }^{-}$uptake with the ${ }^{15} \mathrm{~N}$ tracer method does not allow a determination of the origin of $\mathrm{NO}_{3}{ }^{-}$taken up. At the end of winter, the major part of the $\mathrm{NO}_{3}{ }^{-}$stock in the euphotic layer (for 
example $\mathrm{HFF}_{2,3}$ ) enters with deep water through vertical mixing (Coste et al. 1972). In this situation, the ${ }^{15} \mathrm{~N}$ tracer technique measures essentially new production (sensu Dugdale \& Goering 1967). However, uptake rates measured with the ${ }^{15} \mathrm{~N}$-tracer technique in the $\mathrm{NO}_{3}{ }^{-}$exhausted layer of our area probably reflected $\mathrm{NO}_{3}{ }^{-}$uptake fueled by in situ $\mathrm{NO}_{3}{ }^{-}$production (greatest part) as well as by diffusive upward $\mathrm{NO}_{3}{ }^{-}$fluxes. In stratified conditions, the actual new production is theoretically given by the magnitude of the physical $\mathrm{NO}_{3}{ }^{-}$flux. Unfortunately, it is very difficult to measure directly the diffusive upward $\mathrm{NO}_{3}{ }^{-}$flux and only in one study was an indirect assessment from nutrient consumption (Minas \& Codispoti 1993) obtained for diffusive $\mathrm{NO}_{3}^{-}$flux, ranging between 0.13 and $0.50 \mathrm{mmol}$ $\mathrm{m}^{-2} \mathrm{~d}^{-1}$ in the NW Mediterranean Sea during the lowest summer productivity (September). This latter range represents 11 to $75 \%$ of the euphotic layer depth-integrated rates of nitrification (Table 1) obtained in the present work. Therefore, 25 to $90 \%$ of $\mathrm{NO}_{3}{ }^{-}$uptake estimated with the ${ }^{15} \mathrm{~N}$ tracer may be considered as regenerated production. Consequently, predicted net exports of organic nitrogen from the euphotic layer may probably be considerably lower than the total $\mathrm{NO}_{3}{ }^{-}$based production (Ward et al. 1989). This latter problem raises the question of the validity of the $f$-ratio estimation with the ${ }^{15} \mathrm{~N}$ tracer method in areas where in situ nutrient recycling is important.

\section{DIN loss and new production}

Our data show that a significant part of the DIN taken up ( $-23 \%$ of gross uptake) was lost as DON during the $24 \mathrm{~h}$ incubation experiments. However, it is difficult to ascertain whether the ${ }^{15} \mathrm{~N}$ tracer detected in the DON pool was transferred to this pool solely via direct and active release from living phytoplankton cells. The ${ }^{15} \mathrm{~N}$ excess enrichment in the DON pool may have aIso resulted from cell rupture by grazing (Bronk
\& Glibert 1993, 1994) and from cells lysis by viral infection (Procter \& Fuhrman 1990, Cotrell \& Suttle 1991). In our work, a small fraction of DIN may have been lost before filtration, since small losses of PON $(\sim 7 \%$, see 'Materials and methods') were observed during storage after poisoning. In addition, the magnitude of DIN uptake by organisms passing through GF/F filters and retained on $0.2 \mu \mathrm{m}$ Anopore membranes (i.e. PON < $\mathrm{GF} / \mathrm{F}$ representing the pool of bacterioplankton and submicron algae, Slawyk \& Raimbault 1995) was also checked. Bacterioplankton has been demonstrated to partly pass through GF/F (Lee \& Fuhrman 1987) and to take up preferentially $\mathrm{NH}_{4}{ }^{+}$(Wheeler \& Kirchman 1986). And in the case of an active bacterioplankton community, this pool could have artificially increased the $\mathrm{DO}{ }^{15} \mathrm{~N}$ enrichment of filtrates in ${ }^{15} \mathrm{NH}_{4}^{+}$uptake experiments, sincc a larger percentage of tracer appears in the combined DON pool when $\mathrm{NH}_{4}^{+}$is the substrate, relative to $\mathrm{NO}_{3}^{-}$(Probyn \& Painting 1985, Wheeler \& Kirchman 1986, Bronk \& Glibert 1991, 1994). However, comparisons between net uptake rates measured on GF/F with those measured on $0.2 \mu \mathrm{m}$ filters (see 'Materials and methods') showed that this pathway of loss was negligible. Thus, DIN uptake in the NW Mediterranean Sea during spring could be essentially ascribed to particles $>\mathrm{GF} / \mathrm{F}$ although the area was globally nitrogen-depleted and based on regeneration. However, the increase in ${ }^{15} \mathrm{NH}_{4}{ }^{+}$losses to the DON pool when the upper water column became $\mathrm{NO}_{3}{ }^{-}$exhausted at the end of our survey period (more oligotrophic conditions) could likely show an evolution of microbial communities with the increasing influence of bacterioplankton in nitrogen utilization.

The ${ }^{15} \mathrm{~N}$ mass balance studies on our data showed that on average $82.1 \%$ (95\% CI: [78.5 to 86.0]) and $94 \%$ (95\% Cl: [89.1 to 98.3]) of the ${ }^{15} \mathrm{NH}_{4}{ }^{+}$and ${ }^{15} \mathrm{NO}_{3}{ }^{-}$ tracer added, respectively, were recovered at the end of the uptake experiments. The discrepancies between ${ }^{15} \mathrm{NH}_{4}{ }^{+}$and ${ }^{15} \mathrm{NO}_{3}{ }^{-}$may be attributed to bottle contain-

Table 2. Literature data on DON release rates and corresponding net uptake rates in different marine systems. $1-\left(\rho / \rho_{g}\right)$ repre-

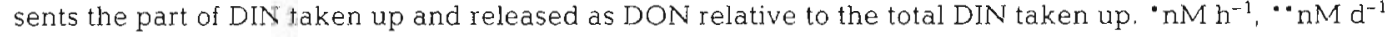

\begin{tabular}{|c|c|c|c|c|c|}
\hline Location & Substrate & Net uptake rates & DO $:$ loss rates & $1-\left(\rho / \rho_{g}\right)$ & Source \\
\hline $\begin{array}{l}\text { Southern California Bight } \\
\text { (coastal area) }\end{array}$ & $\begin{array}{l}\mathrm{NH}_{4}^{+} \\
\mathrm{NO}_{3}\end{array}$ & $\begin{aligned} 48.4^{*} & \pm 4.5 \\
6.3^{\circ} & \pm 0.8\end{aligned}$ & $\begin{aligned} 12.4^{\bullet} & \pm 3.2 \\
3.4^{*} & \pm 0.2\end{aligned}$ & $\begin{array}{l}0.20 \\
0.35\end{array}$ & Bronk et al. (1994) \\
\hline $\begin{array}{l}\text { Chesapeake Bay } \\
\text { (estuarine area) }\end{array}$ & $\begin{array}{l}\mathrm{NH}_{4}^{+} \\
\mathrm{NO}_{3}^{-}\end{array}$ & $\begin{array}{l}100^{\circ} \\
478.4^{\circ}\end{array}$ & $\begin{array}{l}51.8^{\circ} \\
60.6^{\circ}\end{array}$ & $\begin{array}{l}0.34 \\
0.11\end{array}$ & Bronk \& Glibert (1991) \\
\hline $\begin{array}{l}\text { Equatorial Pacific }\left(150^{\circ} \mathrm{W}\right) \\
\text { (open ocean) }\end{array}$ & $\mathrm{NO}_{3}^{-}$ & $0-50^{\cdots}$ & $0-4 \cdot$ & $0.15^{\mathrm{a}}$ & Slawyk et al. (1998) \\
\hline $\begin{array}{l}\text { Gulf of Lions } \\
\text { (coastal area) }\end{array}$ & $\begin{array}{l}\mathrm{NH}_{4}^{-} \\
\mathrm{NO}_{3}^{-}\end{array}$ & $\begin{array}{l}5-62 \cdots \\
3-40 \cdots\end{array}$ & $\begin{array}{l}0-35^{*} \\
0-14\end{array}$ & $\begin{array}{l}0.26^{\mathrm{a}} \\
0.24^{4}\end{array}$ & This study \\
\hline "Averages & & & & & \\
\hline
\end{tabular}


ment effects (Slawyk \& Raimbault 1995). According to the latter authors, adsorption of $\mathrm{NH}_{4}{ }^{+}$onto $\mathrm{PC}$ bottle walls and $\mathrm{NH}_{4}{ }^{+}$uptake by bacteria growing on the walls of PC bottle may explain why ${ }^{15} \mathrm{~N}$ mass balance is more difficult to achieve in $\mathrm{NH}_{4}{ }^{+}$than $\mathrm{NO}_{3}{ }^{-}$uptake experiments, particularly in the case of long incubations. Regardless of the origin of DIN losses, it appears that $p: p_{g}$ ratio data from this coastal Mediterranean system were within the range of values found in the literature (Table 2), i.e. between the low loss rates $(<15 \%)$ found in the Equatorial Pacific by Slawyk et al. (1998) and the very high ones $(74 \%)$ found in the Southern California Bight by Bronk \& Glibert (1991). Our DIN loss rates are much lower (by a factor of 3 or more) than those reported by Colios (1992) and Collos et al. (1992) from algal cultures. However, in these latter studies loss rates were estimated during short incubations. DIN loss may decrease with incubation time: for example, Slawyk \& Raimbault (1995) found that the percentage of DIN taken up and resleased as DON was $41 \%$ after a $2 \mathrm{~h}$ incubation period and decreased to $\sim 20 \%$ after $20 \mathrm{~h}$. The initial high loss may be explained by a stress of the plankton community when the experience was set up, and the subsequent decrease in loss may have resulted from a stoppage of DIN loss and/or bacterial consumption of released DON (Slawyk \& Raimbault 1995). It is worthwhile to note that nitrogen loss rates obtained here were comparable to release rates found for recently fixed photosynthetic products during photosynthesis in algae, i.e. for dissolved organic carbon (Mague et al. 1980, Giordano et al. 1994). Recently, Slawyk et al. (1998) hypothesized that DIN losses greater than $50 \%$ of gross uptake are unlikely in healthy growing phytoplankton populations, since such high loss rates would involve such a high DON release that the PON pool concentration would decrease instead of increase.

One should keep in mind that DIN losses to the DON pool do not represent the total flux of nitrogen from the PON to the DON pool (the true DON release, sensu Bronk \& Glibert 1991). DON release is greater than DIN loss and depends on the ${ }^{15} \mathrm{~N}$ enrichment in the intracellular DON pool. Unfortunately, it appears to be difficult to define the DON source pool of DON release (Slawyk et al. 1998), and thus to measure the ${ }^{15} \mathrm{~N}$ enrichment of this pool.

A final point concerns the impact of gross uptake rate on the computation of the $f$-ratio. In the present work, the $f$-ratio profiles computed from gross uptake rates of $\mathrm{NO}_{3}^{-}$and $\mathrm{NH}_{4}{ }^{+}$( $f_{\mathrm{g}}$ in Fig. 6a) generally paralleled the conventional $f$-ratio profiles, but they were sometimes $\left(\mathrm{HFF}_{4,6}\right)$ more in line with the $\mathrm{NO}_{3}{ }^{-}$and $\mathrm{chl}$ distribution patterns. In contrast to data from Bronk \& Glibert (1994), who found an increase in the $f$-ratio of $50 \%$ in oceanic samples and of $17 \%$ in the coastal
Southern California Bight, a slope obtained from a model II regression analysis (Sokal \& Rohlf 1995) of the relationship between the conventional $f$-ratio and the gross $f$-ratio gave a value of 1.145 (95\% CI: [1.136 to 1.154 ]) with an intercept of -0.004 . The slope was not significantly different from 1 , thus indicating that the inclusion of DIN loss in the computation of $f$-ratios does not change these ratios.

Acknowledgements. This work was supported by the Programme National d'Océanographie Côtière (PNOC-IFREMER-INSU) and by the European program Metro-Med (MAST III). We would like to thank S. Heussner, who managed the HFF project, and F. Van Wambeke, who was the chief scientist of the HFF 'Pelagos' cruises. We are grateful to M. C. Bonin and N. Garcia for technical assistance. G. Slawyk provided constructive comments and suggestions on this manuscript. We thank all those aboard the RVs 'L'Europe' and 'Thetys II' for making this study possible

\section{LITERATURE CITED}

Allen CB, Kanda J, Laws EA (1996) New production and photosynthetic rates within and outside a cyclonic mesoscale eddy in the North Pacific subtropical gyre. Deep-Sea Res II 43:917-936

Bianchi M, Bonin P, Feliatra (1994) Bacterial nitrification and denitrification rates in the Rhône River plume (northwestern Mediterranean Sea). Mar Ecol Prog Ser 103: 197-202

Bronk D, Glibert P (1991) A ${ }^{15} \mathrm{~N}$ tracer method for the nneasurement of dissolved organic nitrogen release by phytoplankton. Mar Ecol Prog Ser 77:171-182

Bronk D, Glibert P (1993) Contrasting patterns of dissolved organic nitrogen release by 2 size fractions of estuarine plankton during a period of rapid $\mathrm{NH}_{4}{ }^{+}$consumption and $\mathrm{NO}_{2}^{-}$production. Mar Ecol Prog Ser 96:291-299

Bronk D, Glibert P (1994) The fate of the missing ${ }^{15} \mathrm{~N}$ differs among marine systems. Limnol Oceanogr 39(1):189-195

Bronk D, Glibert P, Ward B (1994) Nitrogen uptake, dissolved organic nitrogen release and new production. Science $265: 1843-1846$

Cochlan WP (1986) Seasonal study of uptake and regeneration of nitrogen on the Scotian Shelf. Cont Shelf Res $5: 555-577$

Collos Y (1992) Nitrogen budgets and dissolved organic matter. Mar Ecol Prog Ser 90:201-206

Collos Y, Döhler G, Biermann I (1992) Production of dissolved organic nitrogen during uptake of nitrate by Synedra planctonica: implications for estimates of new production in the oceans. J Plankton Res 14:1025--1029

Coste B, Gostan J, Minas HJ (1972) Influences des conditions hivernales sur les productions phyto- et zooplanctoniques en Méditerranée Nord-Occidentale. I. Structures hydrologiques et distribution des sels nutritifs. Mar Biol 16:320-348

Cotrell MT, Suttle CA (1991) Widespread occurrence and clonal variation in viruses which causes lysis of a cosmopolitan, eucaryotic marine phytoplankter, Micromonas pusilla. Mar Ecol Prog Ser 78:1-9

Diaz F, Raimbault P. Conan P (in press) Carbon and nitrogen utilization by phytoplankton during spring in a Mediterranean coastal zone (Gulf of Lions): evidence of smallscale variability. Cont Shelf Res 
Dore JE, Karl DM (1996) Nitrification in the euphotic zone as a source for nitrite, nitrate, and nitrous oxide at Station ALOHA. Limnol Oceanogr 41.(8):1619-1628

Dugdale RC. Goering JJ (1967) Uptake of new and regenerated forms of nitrogen in primary production. Limnol Oceanogr 12:199-206

Dugdale RC, Wilkerson $F(1986)$ The use of ${ }^{15} \mathrm{~N}$ to measure nitrogen uptake in eutrophic oceans: experimental considerations. Limnol Oceánogr 31:673-689

Dugdale RC, Wilkerson F (1988) Nutrient sources and primary production in the Eastern Mediterranean. Oceanol Acta 9(SP): $179-184$

Eppley RW, Peterson BJ (1979) Particulate organic matter flux and planktonic new production in the deep ocean. Nature 282:677-680

Eppley RW, Renger EH (1986) Nitrate-based primary production in nutrient-depleted surface waters off California. Oceanogr Trop 21:229-238

Eppley RW, Renger EH, Harrison WG, Cullen JJ (1979) Ammonium distribution in the southern California coastal waters and its role in the growth of phytoplankton. Limnol Oceanogr 24:495-509

Eppley RW, Garside C, Renger EH, Orellana E (1990) Variability of nitrate concentration in nitrogen-depleted subtropical surface waters. Mar Biol 107:53-60

Feliatra F, Bianchi M (1993) Rates of nitrification and carbon uptake in the Rhone River plume (Northwestern Mediterranean Sea). Microb Ecol 26:21-28

Gentilhomme V, Raimbault P (1994) Absorption et régénération de l'azote dans la zone frontale du courant Algérien (Méditerranée Occidentale): réévaluation de la production nouvelle. Oceanol Acta 17(5):555-562

Giordano M, Davis JS, Bowes G (1994) Organic carbon release by Dunaliella salina (Chlorophyta) under different growth conditions of $\mathrm{CO}_{2}$, nitrogen and salinity. J Phycol 30:249-257

Glibert PM (1982) Regional studies of daily, seasonal and size fraction variability in ammonium remineralization. Mar Biol 70:209-222

Glibert PM, Lipschultz F, McCarthy JJ, Altabet MA (1982) Isotope dilution models of uptake and remineralization of ammonium by phytoplankton. Limnol Oceanogr 27: 639-650

Hanson RB, Robertson CY (1988) Spring recycling rates of ammonium in turbid continental shelf waters off the south-eastern United States. Cont Shelf Res 8:49-68

Harrison WG (1978) Experimental measurements of nitrogen remineralization in coastal waters. Limnol Oceanogr 23: $684-694$

Harrison WG (1983) Use of isotope. In: Carpenter E, Capone $D$ (eds) Nitrogen in the marine environment. Academic Press, New York, p 763-807

Harrison WG, Douglas D, Falkowski P, Rowe G, Vidal J (1983) Summer nutrient dynamics of the Middle Atlantic Bight: nitroyen uptake and regeneration J Plankton Res 5(4): $539-556$

Harrison WG, Platt T, Lewis MR (1987) $f$-ratio and its relationship to ambient nitrate concentration in coastal waters J Plankton Res 9(1):235-248

Harrison WG, Harris LR, Irwin BD (1996) The kinetics of nitrogen utilization in the oceanic mixed layer: nitrate and ammonium interactions at nanomolar concentrations. Limnol Oceanogr 41:16-32

Horrigan SG, Carlucci AF, Willams PM (1981) Light inhibition of nitrification in sea-surface films. J Mar Res 39 $557-565$

Kirkwood DS (1992) Stability of solutions of nutrient salts during storage. Mar Chem 38:151-164
Koroleff $F$ (1969) Direct determination of ammonia in natural waters as indophenol blue. ICES Mar Sci Symp 9:1-6

Laws $E$ (1984) Isotope dilution models and the mystery of the vanishing ${ }^{15} \mathrm{~N}$. Limnol Oceanogr 29:379-386

Lee S, Fuhrman JA (1987) Relationships between biovolume and biomass of naturally-derived marine bacterioplankton. Appl Environ Microbiol 53:1298-1303

Lefèvre D, Minas HJ, Minas M, Robinson C, Williams PJLeB, Woodward EMS (1997) Review of gross community production, primary production, net community production and dark community respiration in the Gulf of Lions Deep-Sea Res 44(3-4):801-832

Mague TH, Friberg E, Hugues DJ, Morris I (1980) Extracellular release of carbon by marine phytoplankton; a physiological approach. Limnol Oceanogr 25:262-279

Millot C (1990) The Gulf of Lion's hydrodynamics. Cont Shelf Res 10:885-894

Minas HJ, Bonin MC (1988) Oxygenation physique et biologique de la Méditerranée Nord-occidentale en hiver et au printemps. Oceanol Acta 9(SP):123-132

Minas HJ, Codispoti LA (1993) Estimations of primary production by observation of changes in the mesoscale nitrate field. ICES Mar Sci Symp 197:215-235

Moutin T, Raimbault P, Golterman HL, Coste B (1998) The input of nutrients by the Rhone River into the Mediterranean Sea: recent observations and comparisons with earlier data. Hydrobiologia 373/374:237-246

Olson RJ (1981a) ${ }^{15} \mathrm{~N}$ tracer studies of the primary nitrite maximum. J Mar Res 39:203-226

Olson RJ (1981b) Differential photoinhibition of marine nitrifying bacteria: a possible mechanism for the formation of the primary nitrite maximum. J Mar Res 39:227-238

Platt T, Jauhari P, Sathyendranath S (1991) The importance and measurement of new production. In: Falkowski PG Woodhead AD (eds) Primary productivity and biogeochemical cycles in the sea. Plenum Press, New York, p 273-284

Preston T, Owens NPJ (1983) Interfacing an automatic elemental analyser with an isotope ratio mass spectrometer the potential for fully automated total nitrogen and 15nitrogen analysis. Analyst 108:971-977

Priscu JC, Downes MT (1985) Nitrogen uptake, ammonium oxidation and nitrous oxide $\left(\mathrm{N}_{2} \mathrm{O}\right)$ levels in the coastal waters of western Cook Strait, New Zealand. Estuar Coast Shelf Sci 20.529-542

Probyn T, Painting SJ (1985) Nitrogen uptake by size-fractionated phytoplankton populations in Antarctic surface waters. Limnol Oceanogr 30:1327-1332

Procter LM, Fuhrman JA (1990) Viral mortality of marine bacteria and cyanobacteria. Nature 343:60-62

Raimbault $P$, Rodier M, Taupier-Letage I (1988) Size fraction of phytoplankton in the Ligurian Sea and the Algerian Basin (Mediterranean Sea): size fraction versus total concentrations. Mar Microb Food Webs 3:1-7

Raimbault P. Slawyk G, Boudjellal B, Coatanoan C, Conan P, Coste B. Garcia N, Moutin T, Pujo-Pay M (1999) Carbon and nitrogen uptake and export in the equatorial Pacific at $150^{\circ} \mathrm{W}$ : evidence of an efficient regenerated production cycle. J Geophys Res 104(C2):3341-3356

Rees AP, Joint I, Donald KM (1999) Early spring bloom phytoplankton-nutrient dynamics at the Celtic Sea Shelf Edge. Deep-Sea Res I 46:483-510

Rowe GT, Smith S, Falkowski o, Whitledge T, Theroux R Phoel W, Ducklow H (1986) Do continental shelves export orqanic matter? Nature 324:544-561

Selmer JS (1988) Ammonium regeneration in the marine environment. PhD thesis, University of Göteborg 
Selmer JS, Ferrier-Pages C, Cellario C, Rassoulzadegan F (1993) New and regenerated production in relation to microbial loop in the NW Mediterranean Sea. Mar Ecol Prog Ser 100:71-83

Slawyk G, Raimbault $P$ (1995) Simple procedure for simultaneous recovery of dissolved inorganic and organic nitrogen in ${ }^{15} \mathrm{~N}$ tracer experiments and improving the isotopic mass balance. Mar Ecol Prog Ser 124:289-299

Slawyk G, Raimbault P, Garcia N (1998) Measuring gross uptake of ${ }^{15} \mathrm{~N}$-labeled nitrogen by marine phytoplankton without particulate matter collection: evidence of $l 0 w{ }^{15} \mathrm{~N}$ losses to the dissolved organic nitrogen pool. Limnol Oceanog 43(7): 1734-1739

Smith SW, McKenzie FT (1991) Comments on the role of oceanic biota as a sink for anthropogenic $\mathrm{CO}_{2}$ emissions. Glob Biogeochem Cycles 5(4):189-190

Sokal RR, Rohlf FJ (1995) Biometry. The principles and practice of statistics in biological research. WH Freeman and Company, New York

Treguer P, Le Corre P (1975) Manuel d'analyse des sels nutritifs dans l'eau de mer. Laboratoire d'Océanographie Chimique. Université de Bretagne Occidentale, Brest

Wafar MV, Le Corre P, L'Helguen S (1995) $f$-ratios calculated with and without urea uptake in nitrogen uptake by phytoplankton. Deep-Sea Res I 42(9):1669-1674

Editorial responsibility: Otto Kinne (Editor), Oldendorf/Luhe, Germany
Walsh JJ, Rowe GT, Iverson RL, McRoy CP (1981) Biological export of shelf carbon is a sink of the global $\mathrm{CO}_{2}$ cycle Nature 291:196-201

Ward BB (1985) Light and substrate concentration relationships with marine ammonium assimilation and oxidation rates. Mar Chem 16:301-316

Ward BB (1986) Nitrification in marine environments. In: Prosser JI (ed) Nitrification. Special publications of the Society for General Microbiology, Vol 20. IRL Press, Oxford

Ward BB (1987) Nitrogen transformations in the Southern California Bight. Deep-Sea Res 34:785-805

Ward BB, Zafiriou OC (1988) Nitrification and nitric oxide in the oxygen minimum of the eastern tropical North Pacific. Deep-Sea Res 35:1127-1142

Ward BB, Talbot MC, Perry MJ (1984) Contributions of phytoplankton and nitrifying bacteria to ammonium and nitrite dynamics in coastal waters. Cont Shelf Res 3 $383-398$

Ward BB, Kilpatrick KA, Renger EH, Eppley RW (1989) Biological nitrogen cycling in the nitracline. Limnol Oceanogr 34(3):493-513

Wheeler PA, Kirchman DL (1986) Utilization of inorganic and organic nitrogen by bacteria in marine systems. Limnol Oceanogr 31:998-1008

Submitted: February 4, 1999; Accepted: November 11, 1999 Proofs received from author(s): April 28, 2000 